\title{
Determination of Potential Health Hazards and Nutritional Attributes of the Fresh and Smoked Freshwater Thin-Lipped Grey Mullet (Liza Ramada)
}

\author{
Olfa Bouzgarrou ${ }^{1}$, Saloua Sadok ${ }^{1}$ \\ Institut National des Sciences et Technologies de la Mer (INSTM), Tunisia
}

\begin{abstract}
In an attempt to cover up the unappealing taste of the freshwater thin-lipped grey mullet (Liza ramada) and to produce a convenient agro-food product, cold smoking was applied to fish fillets followed by vacuum packaging. Based on biochemical, microbiological, and sensorial analysis, several indices were used to monitor the product quality over 60 days of refrigerated storage at $2 \pm l^{\circ} \mathrm{C}$. A different pattern of amine changes occurred following salting and smoking. Except for (his) and (spm); all others amines including cadaverine increased in cold smoked fillets throughout storage. The indices of atherogenicity (IA) and of thrombogenicity (IT) with values of 1.68 and 1.67 respectively, did not show a significant change during storage suggesting a stability of the fatty acids profile. However microbiological analysis limited the shelf life of thin-lipped grey mullet fillets up to 30 days of refrigerated storage. Increase of the microbial load was accompanied by a concomitant and significant $(P<0.05)$ rise of trimethylamine $(T M A-N)$; volatile basic nitrogen $(T V B-N)$ and change in sarcoplasmic and myofibrillar protein profiles in smoked fish fillet. The Ki and $G$ values calculated from ATP-related compounds showed different pattern of change. Analysis of polycyclic aromatic hydrocarbons (PAHs) of fresh and smoked fillets showed undetectable level of benzo(a)pyrene (BaP) and the sum of PAHs $\left(2.45 \mathrm{ng} \mathrm{g}^{-1}\right)$ was far lower than the limit of acceptability. Data submitted to principal component analysis (PCA) showed that cold smoking process was positively correlated with results of TVB- $N, T M A-N$ and HPX.
\end{abstract}

Keywords: Smoked fish, Liza ramada, Biochemical Analysis, Sensorial Analysis, Microbiological analysis, Polycyclic Aromatic Hydrocarbons.

\section{Introduction}

The development of inland capture fishery is becoming an important activity which has the potential to contribute to global food security and to socio-economically viable environment, especially in emerging countries ([1]; [2]). Currently, Tunisia has 27 large dams (over 100 ha) and nearly a hundred of small dams and hill lakes. Among these continental water-reservoirs, only 30 operate in fish farming with several introduced fish species, among which the thin-lipped grey mullet (Liza ramada) [3]. It is a widely distributed freshwater fish, extensively cultivated in ponds and dams as a popular feeding fish and has low economic value because of its strong non-appreciated taste. The exploitation of this species remains below the planned production and its marketing still poses a problem. A solution to this problem could be the production and promotion of valueadded products with higher profit to producer, and which could meet the consumer's expectation. Recent studies showed that, innovation in value addition is globally orientated to convenience foods and to a wider range of high-value-added products including smoked seafood and marketed ready and/or portion-controlled, uniformquality meals [4]. Smoking is probably the oldest known method used for preserving fish; it's now used more for flavor and appearance but also for its nutritious attributes. Thus, smoked meat products exhibit an increased resistance to oxidative changes and preservation of some vitamins due to the positive effect of certain smoke constituents [5]. This processing technique can therefore lead to the production of innovative products that allow fish to be distributed and marketed worldwide ([4] ; [6]).

Although much research has been conducted on the effect of smoking on the quality parameters of many fish species ([7]; [8]), few studies concerned the mullet Mugil cephalus ([9]; [10]; [11]), and no research data are available on smoked freshwater thin-lipped grey mullet (Liza ramada) concerning the nutrition quality and the shelf life. Generating such data for the new fish product is essential and has both health and economic impacts. From the health standpoint, such data are essential for nutritionist to establish nutritional guideline with the necessary information on the different nutrients and compounds that affect human health [12]. From the economic side, the processing enterprise has to comply with the new Food Standard concerning nutrition labelling (CAC/GL-2) by adding nutritional information on the product.

Data are also important to establish the shelf life of the product which is greatly affected by various factors including fish matrix composition, the initial quality of the fish and the smoking procedure. Cold or hot smoking proceeded by a dry or wet salting may be applied to the same fish species, yielding products with different organoleptic attributes and shelf life ([10]; [11]). In this study, the freshwater thin-lipped grey mullet 
(Liza ramada) was dry-salted, cold smoked and then vacuum packed in order to produce a new agro-food product. The objectives are multiples, (i) to assess the effect of such procedure on chemical, microbial and sensory characteristics of smoked vacuum packed fillets during 60 days of refrigerated storage (ii) to establish the nutritional value and shelf life of such product (iii) and to valorise the underutilised fresh water fish by producing an added value product which will be of benefit to small enterprise in emerging countries such as Tunisia. Multiple indices were used and synthetically analysed to produce a practical evaluation of the fish quality.

\subsection{Fish sample}

\section{Materials and methods}

The Thin-lipped grey mullet (Liza ramada) used in this study were caught in summer (August) from "Wed Abid" freshwater reservoir, North of Tunisia. Following capture, the mullets $(10 \mathrm{~kg})$ were immediately ice-stored in boxes and delivered to the laboratory. The fishes were subsequently gutted, washed, headed and filleted. A first tissue sampling was performed on the different fresh fishes fillets $(n=6)$, and samples were immediately stored at $-80^{\circ} \mathrm{C}$ for subsequent analysis in order to establish the initial biochemical statute of the freshwater fish.

\subsection{Smoking procedure}

In the seafood processing enterprise, the fish used for cold smoking were filleted by hand and were then dry-salted on grids for 45 min using refined $\mathrm{NaCl}$, when the dry salting was completed; the excess salt was removed by careful rinsing with cold water. A second tissue sampling was performed by taking part of tissue from different salted fishes fillets $(n=6)$, and samples were immediately frozen at $-80^{\circ} \mathrm{C}$ as above mentioned. The fillets were then smoked for $3 \mathrm{~h}$ at $22-23^{\circ} \mathrm{C}$ using a Raucher FV.V2 HEIZUNG smoking cabinet. After cooling to $2^{\circ} \mathrm{C}$ within $15 \mathrm{~h}$, a third tissue sampling was also realised ( $\mathrm{n}=6$ different fillets). The smoked fillets were then vacuum-packed using a "Multivac" model and finally stored at $2 \pm 1{ }^{\circ} \mathrm{C}$ for 60 days. Tissue sampling was performed on days $1,15,30,45$ and 60 .

\subsection{Proximate composition}

Moisture was determined according to the AOAC method (1990) [13], by drying $1 \mathrm{~g}$ of tissue in an oven at $105^{\circ} \mathrm{C}(\mathrm{n} 1 / 44)$. Ash content was determined by heating for $12 \mathrm{~h}$ in an oven at $525^{\circ} \mathrm{C}$ according to the AOAC method [14], results were expressed as $\mathrm{g}$ ash $/ \mathrm{kg}$ dry weight bases. Total lipids were extracted according to the method of Folch, Lees, \& Stanley, (1957) [15]. by chloroform/methanol (2/1). The aliquot of chloroform layer was evaporated to dryness under nitrogen and the lipids were quantified gravimetrically. For protein assay and sample preparation; $0.45 \mathrm{~g}$ of ground fish meat $(\mathrm{n}=3)$ were weighed to which were added $9 \mathrm{ml}$ of ultrapure water, followed by a homogenisation step. $100 \mu \mathrm{l}$ of the homogenate is diluted with $900 \mu 1$ of ultrapure water, and then $250 \mu \mathrm{l}$ of the sample was taken for subsequent protein analysis according to the modified method of Lowry [16].

\subsection{Sensory evaluation}

Sensory evaluation for smoked mullet fillets was performed using quantitative affective tests as described by Lawless and Heymann (1998) with some modifications [17]. The consumer experiment consisted in product information test. The attributes of the smoked product were evaluated by the institute staff and students $(\mathrm{n}=100)$. The fillets were scored for flavor, odour, texture, juiciness and saltiness attributes using a four-point hedonic scale (4 to 1). The assessors evaluated smoked product for 16 properties including 4 flavor attributes (smoked flavor, neutral, sour taste, rancid), 4 odour attributes (smoke, sour, no odour and rancid), 4 texture attributes (pasty, soft, fatty and crunchy), 4 juiciness attributes (Strong, regular juiciness, low and very low) and 4 saltiness attributes (salty, moderately salted, slightly salty and very slightly salty).

\subsection{Microbiological analyses}

Microbiological counts were made (triplicate) on fresh fillets, salted fillets and smoked fillets after 1day, 30 days, 60 days of storage. Ten grams of sample were taken aseptically into a sterile blender containing sterile ringer solution and blended for $2 \mathrm{~min}$ at low speed. Volumes of $0.1 \mathrm{ml}$ of decimal dilutions of these homogenates were incubated in the culture of Plate Count Agar (Biokar Diagnostics, Beauvais, France). Mesophil counts were determined after incubation for $48 \mathrm{~h}$ at $30^{\circ} \mathrm{C}$ and psychrophil counts were determinate after incubation for 10 days at $5^{\circ} \mathrm{C}$. All microbial counts were converted to-10 logarithms of colony forming units per $\mathrm{g}(\log \mathrm{CFU} / \mathrm{g})$. 


\subsection{Biochemical analysis}

\subsubsection{Determination of total volatile basic nitrogen and trimethylamine}

The total volatile base (TVB-N) and trimethylamine (TMA-N) were determined using flow injection analysis according to the methods of Ruiz-Cappillas and Horner (1999) [18]; and Sadok, Uglow, \& Stephen (1996) [19] respectively.

\subsubsection{Determination of thiobarbutric acid}

The 2-thiobarbituric acid (TBA) assay, as an index for lipid oxidation, was carried out according to the procedure of Genot, (1996) [20].

\subsubsection{Fatty Acids Analysis}

Fatty acid methyl esters (FAMEs) were obtained using the method described by Metcalfe, Schimitz, Pelka, 1966) [21]. A fraction of extracted lipid was saponifed with $0.5 \mathrm{~N} \mathrm{NaOH}$ in methanol followed by methylation in $14 \%$ Boron trifluoride in methanol $\left(\mathrm{BF}_{3} / \mathrm{MeOH}\right)$. The methylated sample was then extracted with n-hexane. All of these reactions were performed in triplicate for each sample. The resulting methylesters were analyzed by gas chromatography using an Agilent Technologies chromatograph $6890 \mathrm{~N}$ (Agilent Technologies, Palo Alto, CA) equipped with a flame ionization detector, a splitless injector and a polar Innowax 30M silica capillary column $(0.25 \mathrm{~mm}$ i.d $* 30 \mathrm{~m}$ length $* 0.25 \mu \mathrm{m}$ film thickness, Agilent Technologies, J\&W Scientific, Folsom, CA). The temperature of the injector and detector were 220 and $275^{\circ} \mathrm{C}$, respectively. Helium was used as a carrier gas with a flow rate of $1.5 \mathrm{~mL} / \mathrm{min}$.

Peaks were identified by comparing their retention times with FAMEs standards (Supelco, Bellafonte, PA). The sequences of fatty acids were ranged according to their chromatographic retention times and the relative values were given as percentages of the total FAMEs. All chemicals were obtained from SigmaAldrich-Fluka Company Ltd. (Poole, Dorset, UK).

\section{Indices of lipid quality}

Index of atherogenicity (IA) and index of thrombogenicity (IT) were calculated from the data on fatty acid composition according to the method of Ulbritch \& Southgate (1991) [22].

Index of atherogenicity (IA): This indicates the relationship between the sum of the main saturated and unsaturated fatty acids classes. The following equation was applied:

$\mathrm{IA}=[(4 \times C 14: 0)+C 16: 0+C 18: 0] / \Sigma$ MUFA $+\Sigma$ PUFA $n-6+\Sigma$ PUFA $n-3$

Index of thrombogenicity (IT): showing the tendency to form clots in the blood vessels. This is defined as the relationship between the pro-thrombogenetic (saturated) and the anti-thrombogenetic fatty acids (MUFAs, PUFAs $n-6$ and PUFAs $n$-3). The following equation was applied:

$I T=(C 14: 0+C 16: 0+C 18: 0) /(0.5 M U F A+0.5 P U F A n-6+3 P U F A n-3+P U F A n-3 / P U F A n-6)$

\subsubsection{Biogenic amines}

Histamine (HIS), cadaverine (CAD), agmatine (SPD) and spermine (SPM) were purchased from Sigma Chemical Co. (St Louis, MO, USA). The standard amines were dissolved in deionised distilled water (DDW) to a concentration of $100 \mathrm{mg} / 100 \mathrm{ml}$ and used as the working solution. Biogenic amines determination followed the method of Moret, Smela, Populin \& Conte (2005) [23].

\subsubsection{Quantitative determination of ATP and its breakdown quantitative products}

Determinations of nucleotides and related compounds were carried out by a reverse phase high performance liquid chromatography procedure (Ryder, 1985) [24].

Purine standards (adenosine 5'-diphosphate (ADP), adenosine 5'-monophosphate (AMP), inosine 5', monophosphate (IMP), inosine (INS) and hypoxanthine (HPX)) were obtained from Sigma Chemical Company Co. (St Louis, MO, USA) and were checked for purity by the method described below.

Based on AMP, IMP, HxR and Hx concentrations, the values Ki [25] and G [26] were calculated:

$$
\begin{gathered}
\mathrm{Ki}(\%)=(\mathrm{HxR}+\mathrm{Hx}) /(\mathrm{IMP}+\mathrm{HxR}+\mathrm{Hx}) \times 100 \\
\mathrm{G}(\%)=(\mathrm{HxR}+\mathrm{Hx}) /(\mathrm{AMP}+\mathrm{IMP}+\mathrm{HxR}) \times 100
\end{gathered}
$$

\subsubsection{Fractionation and Analysis of Muscle Proteins}

Muscle proteins were extracted according to the solubility protocol described by Hashimoto, Watanabe, Kono, \& Shiro, (1979) [27] with low modification. From the extraction procedure, three protein fractions were obtained: sarcoplasmic, myofibrillar and alkali soluble. $0.5 \mathrm{~g}$ mullet muscle was homogenized with 5-mL phosphate buffer $\mathrm{A}\left(15.6-\mathrm{mM} \mathrm{Na}_{2} \mathrm{HPO}_{4}, 3.5-\mathrm{mM} \mathrm{KH}_{2} \mathrm{PO}_{4}, \mathrm{I}=0.05, \mathrm{pH}=7.5\right)$. Extract was centrifuged at 5,000 $\mathrm{g}$ at $4 \mathrm{C}$ for $15 \mathrm{~min}$. The sediment was again mixed with $5-\mathrm{mL}$ phosphate buffer $\mathrm{A}$ and centrifuged as mentioned before. Supernatants of both centrifugation steps, containing sarcoplasmic proteins, were mixed together. The sediment was mixed twice with 5-mL phosphate buffer B (15.6-mM Na $2 \mathrm{HPO}_{4}, 3.5-\mathrm{mM} \mathrm{KH}_{2} \mathrm{PO}_{4}, 0.45-\mathrm{M} \mathrm{KCl,} \mathrm{I}$ 
Determination of potential health hazards and nutritional attributes of the fresh and smoked ..

$=0.5, \mathrm{pH} 7.5)$ and centrifuged as mentioned earlier. This supernatant contained the myofibril fraction. Protein concentration was quantified as described by Bradford (1976) [28].

\section{Electrophoresis}

Electrophoresis of protein fractions was analyzed on SDS-PAGE according to the method of Laemmli (1970) [29]. Protein separation was carried out by gel electrophoresis (sodium dodecyl sulfate-polyacrylamide gel electrophoresis) under reducing conditions, using a discontinuous gel containing $10 \%$ acrylamide.

\subsubsection{Quantitative determination of polycyclic aromatic hydrocarbons}

Polycyclic aromatic hydrocarbons were determined according to the UNEP/IOC/IAEA (1995) method [30] using a GC-MS (gas chromatograph coupled to a mass spectrometer). The hexane, dichloromethane (DCM) and methanol $(\mathrm{MeOH})$ used were high-purity solvents (Burdick and brand Jackson). Anhydrous sodium sulphate $\left(\mathrm{Na}_{2} \mathrm{SO}_{4}\right)$, active aluminium oxide (90) and silica gel 60 for column chromatography used for cleaning were supplied by Fluka. A PAH standard mixture was provided by International Atomic Energy Agency (IAEA). Before treatment, thin-lipped grey mullet muscle samples, previously stored at $-80{ }^{\circ} \mathrm{C}$, were lyophilised and then hand-ground using mortar and pestle in liquid nitrogen. Sample comparisons were made with reference material (IAEA 406) for quality control purposes. More details were included in the method described by Bouzgarrou et al. (2015) [11].

\subsection{Statistical analyses}

For each lot and at each sampling time, the results are presented as mean \pm standard deviation (SD) of (n) fillets. The values relatives to the chemical composition of the fresh and smoked fillets at different times of storage were compared by one-way ANOVA. If significant differences $(\mathrm{P}<0.05)$ between means were obtained, Tukey's honest significant test was used to differentiate between means. Statistics were performed using SPSS 20 software for windows (SPSS Inc., Chicago, IL, USA). The chemical values, as well as the respective perceptual changes through processing, were also explored by principal component analysis (PCA) [31]. This was done to visualise, and thus improve, the interpretation of the relative changes in chemical composition found in the different fillets. PCA was carried out by the multivariate statistical software (The Unscrambler version 9.8, CAMO Software AS, Oslo, Norway).

\subsection{Sensory analysis}

\section{Results and discussions}

Sensory evaluation is a crucial part in food development because it determines how consumers will react towards a new product. It is generally assumed that consumer prime consideration for selecting and eating a new food commodity is the product's palatability and quality, nutritional and wholesomeness attributes came in a second order [17]. The overall fish eating satisfaction can be attributed to five factors: flavor, odour, texture, juiciness and saltiness. Figure1 shows consumer overall acceptance with the intensity of a descriptive panel attribute (flavor intensity, odour intensity; texture intensity; juiciness intensity; degree of salting). Considering the sensory parameters the consumers have a better appreciation for the peculiar flavor and odour specific to smoking (Fig.1), and the soft texture with an average juiciness. Regarding degree of salting, consumers appreciated better the moderately salty smoked product. As reported in other communities [32]; moderately salted fish had better overall acceptance.

\subsection{Monitoring proximate analysis variations in processed and stored mullets fillets}

The variations of the proximate composition of raw, salted and smoked Liza ramada fillets during 60 days of refrigerated storage are summarised in Table 1. Determination of moisture content is important considering the implication of such parameter in organoleptic and product preservation effects, but it is also considered an important criterion in labelling smoked product [33]. Initially, the mean moisture content measured in fresh fillets was lower $(78.3 \%)$ than values $(80.7-81.1 \%)$ reported in other study for L. ramada [34]. Such difference may be related to a difference in the sampling season (summer $v s$ winter, respectively), as moisture variation is affected by several factors including season. As expected, the salting and smoking process resulted in a significant decrease $(\mathrm{P}<0.05)$ of moisture content reaching value of $66.71 \pm 1.23 \%$ following the smoking process. Throughout storage, moisture content remained unchanged up to 45 days and then decreased significantly towards the end of storage to reach $56.60 \%$. Such change may reflect the limit of storage of the smoked fillets and may be used as a criterion to establish the shelf life of the product for about 45 days of refrigerated storage at $2^{\circ} \mathrm{C}$. Results relative to ash variation (Table 1) showed significant differences $(\mathrm{P}<0.05)$ in ash content in fresh, salted and smoked fillet of Liza ramada. Due to the salting and smoking dehydrating effects, salt content was higher in the salted/smoked than in fresh fillets. Similar results were reported in other study [35]. Significant decrease in ash content was observed after 45 days of storage, indicating salt leaching 
with water as above mentioned. Comparatively to other study [34], the initial lipid contents found in L. ramada fresh fillet was much higher in this study ( 0.47 vs $4.5 \mathrm{~g} / 100$, respectively). Such results are concordant with moisture data, as both parameters vary inversely. Following the salting step, lipid contents decreased significantly $(P<0.05)$ in fish fillets as a consequence of the salt hydrolytic effect on lipids [36]. After smoking and throughout the storage period at $2^{\circ} \mathrm{C}$, lipid content continued to decreased exponentially $\left(\mathrm{R}^{2}=0.98\right)(P$ $<0.05)$ due to lipid oxidation as revealed by the concomitant exponential $\left(\mathrm{R}^{2}=0.88\right)$ increase of TBArs (Table 2). This finding is in accordance with those reported by Espe et al. 2002 [37].

The protein level (Table 1) found in the freshwater thin-lipped grey mullet fresh fillets $(17.9 \mathrm{~g} / 100 \mathrm{~g})$ was in the range of values reported by Kalay, et al., (2008) [34] as in general, protein levels are not affected by seasonal change. After cold smoking, protein concentration increased slightly $(18.84 \pm 1.06 \mathrm{~g} / 100 \mathrm{~g})$ as a result of loss of water content. During refrigerated storage, protein levels showed a significant decrease after 30 day of storage with a pronounced drop toward the end of storage (60 days) indicating an important deterioration of the smoked fillets.

\subsection{Microbiological analysis}

The changes in mesophilic and psychrophilic counts (MC and PC respectively) of thin-lipped grey mullet fillets as a function of treatment and storage time are shown in Fig. 2(A-B respectively). The initial total viable counts as MC and PC in fillets were 3.89 and $3.57 \log$ CFU/g respectively, indicating the good quality of processed fish fillet [38]. Salting induced a significant MC and PC increases, however smoking significantly (P $<0.05$ ) reduced such counts. Our results are in agreement with other authors ([39], [40]; [41]; [42]) who reported that smoking significantly $(\mathrm{p}<0.05)$ reduced the total aerobic count to values much lower than that found in the corresponding fresh fish products. Such results are due to the antimicrobial effect of smoke polyphenols. During storage, a relative increase in microbial load of smoked product was observed, without however, reaching the upper limit of product rejection. Thus, smoking and refrigerate storage of cold smoked mullet resulted in a microbiological shelf life up to 60 days.

\subsection{Biochemical parameters variations in fresh and smoked fillets}

\subsubsection{Trimethylamine and total volatile bases changes}

The trimethylamine (TMA) and total volatile bases (TVB) variations during the smoking process and refrigerated storage are presented in Table 2. Fresh thin-lipped grey mullet fillets showed initial low levels of TMA and TVB content $(1.27 \pm 0.36 \mathrm{mg} \mathrm{N} / 100 \mathrm{~g}$ and $9.96 \pm 0.74 \mathrm{mg} \mathrm{N} / 100 \mathrm{~g}$ respectively) indicating the good quality of the product, These values are similar to initial values of the freshwater mullet M. cephalus reported in previous study [11]. However, these values are lower than values reported in other studies for marine $M$. cephalus [43]. This difference may be attributed to the origin of the fish as marine fish muscles contain higher amount of non-protein nitrogen [44] precursor of post-mortem TVB-N formation.

Following salting, TMA content remained unchanged $(\mathrm{P}>0.05)$ whereas TVB levels decreased significantly $(\mathrm{p}<0.05)$ - possibly due to the elimination of small volatile bases (i.e. methylamine and dimethylamine) during the washing step. Apart from its organoleptic trait, salting has a preservative effect as a consequence of the reduction of water activity [45]. After the smoking step and throughout refrigerated storage, both TMA-N and TVB levels (Table 2) showed exponential increases $\left(R^{2}=0.83\right.$ and 0.94 respectively). Such increases were caused by a combination of microbiological and autolytic deamination of amino acids and the microbial reduction of TMAO and other nitrogenous compounds to TMA [46]. In this study the TMA level $(11.02 \mathrm{mg} / 100 \mathrm{~g})$ reached the limit set by (Commission Regulation, EC- NO 2074/2005) at day 45. However TVB content remained lower than value the limits of TVB-N for fishery products in Commission Regulation (EC) NO 2074/2005, which was ranged between 25 to 35 milligrams of nitrogen/ 100grams of fish flesh. Therefore to ensure a maximum safety for consumer, a concentration of $15 \mathrm{mg}$ TVB-N/100g can be proposed as the threshold indicating potential spoilage of smoked vacuum packed mullet fillet; limiting their shelf life to 45 days of storage at $2^{\circ} \mathrm{C}$.

\subsubsection{Thiobarbituric acid (TBA-rs) variation}

The variation of the thiobarbituric acid index which measures the malondialdehyde (MDA), an endproduct of lipid oxidation [47], is presented in Table 2. The initial TBA-rs value (0.18 $\mathrm{mg} \mathrm{MDA} / \mathrm{kg})$ in Liza ramada flesh was low indicating the good fish quality. Beside, such value is lower than the level of 0.469 MDA $/ \mathrm{kg}$ reported for the fresh mullet Mugil cephalus [43].

After salting, significant increase $(\mathrm{p}<0.05)$ in TBA-rs value was observed in mullet fillets. This may indicate the oxidative decomposition at the double bonds of unsaturated fatty acids as significant drop of lipid was observed after salting (Table 1). The pro-oxidant activity of salt is well established [48], although it is commonly used for the preservation of meat and fish because of its withdrawal of free water, as well as it inhibiting action on enzymes and bacteria activity. Smoking in contrast, significantly $(p<0.05)$ lowed TBA-rs 
values (Table 2). This fact can be attributed to the washing operation which eliminated the oxidation products and to the antioxidant activity of phenolic constituents of smoke deposited into the fillet as reported in other study [49]. Such effect is confirmed by the moderate, but significant $(\mathrm{P}<0.05)$ increase of the TBA-rs levels in smoked samples throughout the storage period. In concordance with the other studied indices, In conclusion and taking into account TMA index which attained first the onset of flesh deterioration, the value of $0.73 \mathrm{mg}$ $\mathrm{MDA} / \mathrm{kg}$ can be proposed as the threshold for the acceptability of smoked fish.

\subsubsection{Determination of fatty acid composition}

The fatty acid composition of the total lipids in fresh, salted and smoked fillet is presented in Table 4. In fresh Liza ramada muscle, saturated fatty acids (SFAs; $48.59 \%$ ) represent the bulk of the total identified FA, followed by the monounsaturated (MUFAs; $24.08 \%$ ) and the polyunsaturated fatty acids (17.78 \%). Although the mullet in this study is of freshwater origin, their fatty acid rankings are in accordance with the results found for marine mullet Liza aurata) caught in the summer from the Tunisian coast [50]. Within these groups, the major fatty acids were palmitic acid $(\mathrm{C} 16: 0=34.32 \%)$, palmitoleic acid $(\mathrm{C} 16: 1 \mathrm{w} 7=12.70 \%)$ and oleic acid $(\mathrm{C} 18: 1 \mathrm{w} 9=9.52 \%)$. These results are slightly different with previous studies on fatty acids for marine mullet Liza ramada [50] Such difference may be due to fish origin with different environmental conditions including salinity and temperature [51]. The sum of SFA of fish fillets increased following salting and decreased following cold-smoking, but wasn't affected by the storage period. On the other hand, MUFAs showed an important decrease in salted fish fillets following by an important increase after cold- smoking which may be due to the dehydrating effect caused by smoking. Considering the PUFA profile, the relative proportion $(17.78 \%)$ in fresh thin-lipped grey mullet fillets was slightly lower than value $(19.67 \%)$ found for Liza aurata [50]. The relative proportion of the n-3 fatty acids (7.86\%) in fresh mullet fillets was lower than value found in marine mullet (Liza aurata) with values ranging between 14.47-21.84\% measured during the same season. Whereas, the relative proportion of the n-6 fatty acids (7.67\%) in fresh thin-lipped grey mullet fillets was significantly higher $(6.04 \%)$ than value found in marine mullet (Liza aurata) which ranged between $(3.56-3.2 \%)$ and slightly higher than value found by Bouzgarrou et al. (2015) [11] in freshwater mullet (6.04\%). Such difference may be due to fish origin with different environmental conditions [51]. The content of polyunsaturated fatty acids n-3, DHA C22: $6 \mathrm{n}-3$ is similar $(0.70 \%)$ with value reported in previous study for freshwater mullet [11], EPA C20:5n-3 meanwhile remains at fairly moderate $(1.80 \pm 0.01 \%)$. Similarly, Khitouni, et al. [50] reported a moderate level of EPA in fresh golden grey mullet captured in the summer.

The sum of PUFA n-3 increased significantly from $7.86 \%$ to $10.67 \%$ following the salting step contrary to the sum of PUFA n- 6 that underwent a decline. The step of salting has a conservative effect on fatty acids in the W3 series.

Following smoking, EPA $(1.8 \%)$ increased significantly $(\mathrm{P}<0.05)$ to $3.3 \%$ in fillets and was accompanied by an increase in the concentration of DHA (Table 4).

The effect of cold smoking on lipid stability appears towards the end of the refrigerated storage as revealed by stability of the sum of PUFA, MUFA and SFA in fillets. In contrast, during hot smoking PUFA degradation is significant and it is more pronounced for omega-3 [11]. Concerning lipid quality indices, IA and IT were proposed as nutritional indicator [52]. In this study, the IA and IT (Table 4) were found higher than values reported for freshwater mullet $L$. aurata [11]. These differences may be due to a difference in the sampling season but also to the ecological and physiological attributes of fish which significantly affect the lipid fatty acids composition. Following cold smoking, only IT index showed a significant drop and both indices remained stable throughout 60 days of storage. Such results suggest that thin-lipped grey mullet is less affected by smoking than other species such as shrimp [53]. Such results suggest that cold smoking have an important preservative effect on the lipid nutritional quality of thin-lipped grey mullet fillet.

\subsubsection{Biogenic amines}

Biogenic amines determination has both food safety and quality issues. The concentrations of biogenic amines in fresh, salted and smoked fillets of Liza ramada stored at $2 \pm 1{ }^{\circ} \mathrm{C}$ during 60 days are given in table 4. Low initial concentrations of biogenic amines were detected in fresh fillets of thin-lipped grey mullet. Agmatine is the dominant amine with a value of $(27.35 \mathrm{mg} / \mathrm{kg})$ followed by spermine $(2.12 \mathrm{mg} / \mathrm{kg})$ then histamine $(1.425$ $\mathrm{mg} / \mathrm{kg}$ ). No data are available on freshwater Liza ramada for a comparative study, however our values were similar to that reported in red mullet (Mullus barbatus) muscle with values of $25.8,4.7$ and $0.8 \mathrm{mg} / \mathrm{kg}$ for agmatine, spermine and histamine respectively [54].

After cold smoking, the levels of agmatine and histamine significantly decreased with the appearance of cadaverine. Such change could be explained by the transformation of agmatine to cadaverine since agmatine may be used as a precursor of cadaverine [55]. Throughout refrigerated storage, agmatine and cadaverine increased to reach significant changes $(\mathrm{P}<0.05)$ after 45 days of cold storage. Such changes in biogenic amines contents could be due to autolytic reactions occurring in fish muscle ([56]; [57]). In the present study, 
cadaverine values of smoked fillets reached $9.21 \mathrm{mg} / \mathrm{kg}$ towards the end of cold storage, but remained lower than limit established for salmonoids [58]. Taking in account the threshold for TMA level reached following 30 days of storage, a corresponding value of $5 \mathrm{mg} / 100 \mathrm{~g}$ for cadaverine can be proposed as a limit for smoked thinlipped grey mullet.

\subsubsection{Nucleotide catabolism}

Postmortem degradation of adenosine 5'-triphosphate (ATP) in fish muscle occurs due to endogenousenzymatic activity. This degradation goes through the intermediate products adenosine 5'-diphosphate (ADP), and adenosine 5'-monophosphate (AMP), inosine 5' monophosphate (IMP), inosine (INS) and hypoxanthine (HPX) [59]. The adenosine nucleotides and their catabolites have been used as indicators of freshness in several species ([60]; [61]). The values $\mathrm{Ki}$ and G calculated from AMP, IMP, HxR and Hx concentration in fresh fillets, salted fillets and smoked fillets stored at $2 \pm 1{ }^{\circ} \mathrm{C}$ during 60 days are represented in Figure 4 . These values have been proposed as quality index due the differences that species present in relation to mechanisms of degradation of nucleotides [62]. Ki value was suggested by Karube et al. [25] to replace K (Saito et al, 1959)[63] and does not take into consideration the degradation to IMP, because in some species this process occurs very fast impairing the identification of those compounds.

In fresh fillets, the $\mathrm{Ki}$ and $\mathrm{G}$ value were as average of $62 \%$ and $55 \%$. This values is higher to $\mathrm{Ki}$ and $\mathrm{G}$ value in other species of mullet (Mugil platanus) reported by Da Costa Silva Andrade et al. (2014) [64]. These results are relation to the variation of initial nucleotide contents is associated with differences among species, season, catching year, and stress during fish death, water temperature, and the time between catch-slaughter and storage [65].

The high \% of $\mathrm{Ki}$ and $\mathrm{G}$ value in fresh fish indicated a rapid degradation of ATP into IMP.

After salting step the the Ki and G value increased significantly. This increase may be due to the salting effect. Thus, Reddi, (1972) [66] demonstrated that enzyme activity was inhibited strongly by the presence of salt with virtually no activity remaining after 25 -hour incubation in the presence of $5 \%$ sodium chloride.

After the smoking step, levels of $\mathrm{Ki}$ and $\mathrm{G}$ did not show significant changes $(\mathrm{P}>0.05)$. After 30 days of storage, we noted a slightly increase of $\mathrm{Ki}$ value but $\mathrm{G}$ value remained stable indicating the preservation of quality of smoked fillets of thin-lipped grey mullet by cold smoking during 30 days of refrigerated storage. At the end of storage $\mathrm{Ki}$ and $\mathrm{G}$ value increased significantly $(\mathrm{P}<0.05)$ reflecting the degradation of the smoked product.

\subsubsection{Determination of protein profiles by SDS-PAGE}

Changes in electrophoretic profiles of sarcoplasmic protein (SPP) and myofibrillar protein (MFP) of fresh, 30 and 60 days-stored/smoked fillet are shown respectively in Figure 3 (A-B). Sarcoplasmic proteins are mostly hydrolases; this fraction includes proteases. When muscle is thawed, they are released and activated. They may hydrolyze peptide band of major muscle proteins (myofibrillar fraction), thus affecting the tridimensional structure. After SDS-PAGE separation, SPP extracts of fresh fillets thin-lipped grey mullet (Fig. 3A) (P1, P2) contained 15 principal bands with a relative molecular weight of 108, 102.3, 95.4, 78, 67.6, 52.6, 50, 47.8, 45, 36, 31, 27, 19, 14.4, 10.7.

Electrophoregram of SSP extract of fresh and smoked fillet (P3, P4) of thin-lipped grey mullet showed small changes between the two fillets. These changes consist to disappearance of bands of high molecular weight $(1,2,3,4)$ indicating the degradation of these proteins. At the same time an intensification of the band (14) and apparition of the band (A) with the relative molecular weight (20.4 Kda) probably due to accumulation of degradation products of proteins of higher molecular weight.

Comparison of SPP profile among smoked fillets just after cold smoking (P3, P4) and after 1month of refrigerated storage (P5) did not show evident differences between both smoked fillets. In general terms, no substantial changes were observed in the SSP extract profiles of smoked thin-lipped grey mullet fillets as a consequence of 30 days of storage at $2 \pm 1{ }^{\circ} \mathrm{C}$.

However after 60 days, electrophoregram of SSP extract (P6) showed the decrease of bands density of smoked fillets indicating the onset of product degradation. At the same time an intensification of the band of lower molecular weight indicated the accumulation of protein degradation products. MFP extracts of fresh fillets thin-lipped grey mullet (Fig. 3B) (P1, P2) contained 9 principal bands after SDS-PAGE separation with a relative molecular weight of 109.1, 108, 78, 66.2, 45, 42, 32, 18 and $16 \mathrm{kDa}$. These bands of 108, 42, 32, 18 and $16 \mathrm{kDa}$ were tentatively identified as myosin heavy chain (MHC), $\alpha$-actinin ( $\alpha$-ACN), actin (AC), tropomyosin (TMP) and myosin light chains (MLC) respectively [67].

The current study divulged small changes after cold smoking in 108-78-kDa area indicating the degradation of these proteins that concurred relatively with the smoking procedure. In parallel apparition of bands $(\mathrm{a}, \mathrm{b}, \mathrm{c}, \mathrm{d}, \mathrm{e})$ corresponding to proteins with respective molecular weight $(61.65,55,39.8,28.8,8.12)$ in the profiles (3) and (4). Lund and Nielsen (2001)[68] studied changes in myofibrillar proteins from smoked 
salmon after different storage periods, using SDS-PAGE, observed also that several bands appeared or increased in intensity in the $150-43 \mathrm{kDa}$ range.

The disappearance of the MHC band and no change in the actin band indicates proteolysis of large cytoskeletal proteins, with molecular weights too large to be detected on the gel.

The apparition of protein of $55 \mathrm{kDa}$ (band a) identified by desmin, was known as calpain substrate, activation of calpain might explain breakdown of this myofibrillar protein which, in turn, may influence muscle-LHC [69]. Some of the changes seen in the smoked fillet may be due to salt effect. It has been shown that the conformation of the myofibrillar proteins may change as a result of increased salt content in the muscle, making the proteins more susceptible to be attacked by endogenous proteases [70].

After 30 days of-storage we noted disappearance of band (3). This indicates the initiation protein degradation. A pronounced degradation was noticed with storage time leading to the disappearance of bands (3) and (6) probably due to enzymatic proteolysis of the myofibrillar proteins causing structure disruption and postmortem softening as reported in other studies [71]. This finding supports the explanation related to biogenic amines increase following 30 days of storage.

In conclusion, the smoking process increased the formation of the degradation products, but did not change the cleavage pattern and increased the activity of muscle proteases. This result is in accordance with result of Hultmann, (2003)[70].

\subsubsection{Quantitative evaluation of polycyclic aromatic hydrocarbons in fresh and smoked flesh}

The contents of PAHs compounds in fresh and smoked fillet of thin-lipped grey mullet are presented in Table 5. Freshwater Liza ramada presented very low concentration $\left(0.78 \mu \mathrm{g} \cdot \mathrm{kg}^{-1}\right)$ of PAHs in fresh fillets. The previous study of Bouzgarrou et al. [11] has also reported low PAHs levels $\left(0.82 \mu \mathrm{g}^{\mathrm{kg}}{ }^{-1}\right)$ in the freshwater mullet fillets (Mugil cephalus). Such results suggest the absence of contamination with PAHs in the freshwater fish reared in this barrage.

In smoked fillets, the amounts of the low molecular weight PAHs such as naphthalene, acenaphthylene, acenaphthene, pyrene, fluorene, cadalene, phenanthrene, anthracene, fluranthene, pyrene were found higher than the high molecular weight PAHs such as benzo(b)fluoranthene, benzo(k)fluoranthene, benzo(g,h,i)perylene. Moret and Conte [72] was reported that the PAHs with higher molecular weight are more carcinogenic than the lower molecular weight PAHs. As found in liquid smoking procedure [73]; cold smoking as performed in the present study, did not induce contamination with carcinogenic PAHs such as BP, which may arise during smoking. Chrysène, considered less dangerous than benzo[a]pyrène, was not detected in smoked fillet of thinlipped grey mullet. The sum of the $4 \mathrm{PAHs}$ (chrysene, benzo[b]fluoranthene, benz[a]anthracene and $\mathrm{BaP}$ ) of cold smoked thin-lipped grey mullet was $0.47 \mu \mathrm{g} / \mathrm{kg}^{-1}$. This value was far below the maximum limit $\left(12 \mu \mathrm{g} . \mathrm{kg}^{-1}\right)$ fixed by the European Commission (EC 2011) [74] for smoked fish. The above results are in agreement with previous study related to smoked freshwater fish realised in our laboratory [11].

\subsection{Principal component analysis}

A PCA analysis was performed in order to examine the influences of the smoking procedure and storage time on the potential interrelations of fish fillets quality parameters including TVB-N, TMA-N, TBA-rs, lipids, SFA, MUFA, PUFA, AGM, CAD, HIS, SPM, ATP, ADP, AMP, IMP, INO and HPX.

Two principal components (PCs) were found to explain $96 \%$ of the variations in the dataset. The scores and loadings of PC1 and PC2, representing $66 \%$ and $30 \%$ of the total variation, are given in Figure 4. Along the PC1 axis we note that cold smoking treatment was negatively correlated with TBA-rs and agmatine, while storage time was positively correlated with nitrogenous indicators including TVB, TMA and hypoxantine. Along the PC2 axis, we observed that cold smoking is in the positive side while the moisture, lipids, fatty acids (MUFA, PUFA, w6, w3), ATP, ADP, AMP and IMP are in the negative side. Accordingly, we suggest that cold smoking maintained the preservation of fish fillets by preserving the lipids and fatty acids specially PUFA (w3 and w6) degradation. In general, results suggest that smoking preserved fish fillet by delaying lipid oxidation, as reflected by the decreased level of TBA-rs, and by inhibiting bacterial growth as reflected by the reduced the production of nitrogenous compounds.

\section{Conclusions}

The nutritional values of fresh and smoked fillets of the mullet Liza ramada were established in this study. Such newly generated data constitute the building blocks of nutritional and epidemiological information, and are essential not only to nutritionist who try to influence food consumption into more attractive way, but also to food marketers who will use it as a tool in product differentiation. Cold smoking enhanced the physicochemical and sensorial attributes of one of the cheapest and most available inland freshwater fish. Smoked mullets can be consumed up to 30 days of cold storage $\left(<4^{\circ} \mathrm{C}\right)$, it can also represent a variety in the diet with an important source of protein and vital micronutrients. 


\section{Acknowledgements}

This work was supported by a European grant through the project BIOVecQ (PS1.3_08) financed by the Cross-border cooperation program Italy-Tunisia in the frame of the European Neighborhood and Partnership Instrument IEVP-2007-2013 as well as a grant from IRESA (Institution de la Recherche et de l'Enseignement Supérieur Agricoles) -Ministry of Agriculture. The authors acknowledge the fish processing plant (HORCHANI Company) for allowing fish smoking and the Society of Trident of Carthage (Tunisia) for supplying thin-lipped grey mullet samples.

\section{References}

[1]. S.J. Youn, W.W. Taylor, A.J. Lynch, I.G., T.D. CowxBeard Jr., D. Bartley, and F. Wu, Inland capture fishery contributions to global food security and threats to their future, Review. Global Food Security, 3(3-4), 2014, 142-148.

[2]. M. Chaikumbunga, H. Doucouliagos, and H. Scarborough, The economic value of wetlands in developing countries: A metaregression analysis. Ecological Economics, 124, 2016, 164-174.

[3]. DGPA. (2015). Fisheries statistics. Directorate General of Fisheries and Aquaculture, Tunisia.

[4]. FAO. Food And Agriculture Organization of the United Nations. (2016). The state of world fisheries and aquaculture: Contributing to food security and nutrition for all. $190 \mathrm{pp}$.

[5]. J.R. Burt, The effects of drying and smoking on the vitamin content of fish. (Ed.), In Fish Smoking and Drying. London, UK: Elsevier. 1988 p. 53-61

[6]. FAO. Food And Agriculture Organization of the United Nations (2014). The state of world fisheries and aquaculture: Opportunities and challenges. $223 \mathrm{pp}$.

[7]. M. Cardinal, H. Gunnlaugsdottir, M. Bjoernevik, A. Ouisse, J.L. Vallet, and F. Leroi, Sensory characteristics of cold-smoked Atlantic salmon (Salmo salar) from European market and relationships with chemical, physical and microbiological measurements. Food Research International, 37, 2004, 181-193.

[8]. I. S. Arvanitoyannis and K.V. Kotsanopoulos, Smoking of Fish and Seafood: History, methods and effects on physical, nutritional and microbiological properties, Food and Bioprocess Technology, 5(3), 2012, 831-853.

[9]. B.J.O. Efiuvwevwere, and H. A. Iweanoge, Microbiological and physico-chemical quality of various tissue types of fresh and potassium sorbate-treated and untreated smoked mullet (Mugil cephalus). Word Journal of Microbiology and Biotechnology, 7(5), $1991,562-566$

[10]. F.R. Antoine, M.R. Marshall, C.A. Sims, S.F. O'keefe, and C.I. Wei, Phosphate Pretreatment on Smoke Adsorption of Cold Smoked Mullet (Mugil cephalus), Journal of Aquatic Food Product Technology, 9(2), 2000, 69-81.

[11]. O. Bouzgarrou, N. El Mzougui, and S. Sadok, Smoking and polyphenols' addition to improve freshwater mullet (Mugil cephalus) fillets' quality attributes during refrigerated storage, International Journal of Food Science and Technology, 51, 2015, 268-277.

[12]. I. Elmadfa, A. L. Meyer, Importance of food composition data to nutrition and public health. European Journal of Clinical Nutrition, 64(3), 2010, 4-7.

[13]. AOAC. (1990). Official methods analysis (16 th ed.). Washington DC: Association of Official Chemists

[14]. AOAC. (1995). Official methods analysis (16 th ed.). Washington DC: Association of Official Chemists.

[15]. J. Folch, M. Lees and G.H.S. Stanley, A simple method for the isolation and purification of total lipids from animal tissue, Journal of Biological Chemistry, 52, 1957, 497-509.

[16]. Analytical Biochemistry. 48(2), 1972, 422-7.

[17]. H.T. Lawless, and H. Heymann, Sensory Evaluation of Food: Principles and Practices. New York: Chapman \& Hall , 1998. Pp: 1950.

[18]. C. Ruiz-Cappillas, W.F.A. Horner, Determination of the trimethylamine and total volatile basic nitrogen in flesh fish by flow injection analysis, Journal of the Science of Food and Agriculture, 14(79), 1999, 1982-1986.

[19]. S. Sadok, R. Uglow, J.H. Stephen, Determination of trimethylamine in fish, by flow injection analysis, Analytica Chimica Acta, 32, $1996,69-74$

[20]. C. Genot, Some factors influencing TBA test. In Report of diet-ox project (AIRIII-CT-92-1577). (1996).

[21]. L.D. Metcalfe, A.A. Schmitz, J.R. Pelka, Rapid preparation of fatty acids esters from lipids for gas chromatographic analysis, Analytical Chemistry, 38, 1966, 524-535.

[22]. T.L.V. Ulbritch and D.A.T. Southgate, Coronary heart disease. seven dietary factors. Lancet, 338, 1991, 985-99.

[23]. S. Moret, D. Smela, T. Populin, L.S Conte, A survey on free biogenic amine content of fresh and preserved vegetables, Food Chemistry, 89, 2005, 355-361.

[24]. J.M. Ryder, Determination of adenosine triphosphate and its breakdown products in fish muscle by high-performance liquid chromatography. Journal of Agricultural and Food Chemistry, 33, 1985, 678-680.

[25]. I. Karube, H. Matsuoka, S. Suzuki, E. Watanabe, and K. Toyama, Determination of Fish Freshness with an Enzyme Sensor System. Journal of Agriculture and Food Chemistry, 32, 1984, 314-319. http://dx. doi.org/10.1021/jf00122a034.

[26]. B. G. Burns, P. J. Ke, and B. B. Irvine, Objective procedure for fish freshness evaluation based on nucleotide changes using a HPLC system. Canadian Technical Report of Fisheries and Aquatic Sciences, 1373. 1985

[27]. K. Hashimoto, S. Watanabe, M. Kono, K. Shiro, Muscle protein composition of sardine and mackerel, Bulletin of the Chemical Society Japan, 45, 1979, 1435-1441.

[28]. M.M. Bradford, A rapid and sensitive method of the quantitation of microgram quantities of protein utilizing the principal of protein-dye binding. Analytical biochemistry, 72, 1976, 248-254.

[29]. U.K. Laemmli, Cleavage of structural proteins during the assembly of the head of bacteriophage T4. Nature, 227 (6), 1970, 80-685.

[30]. UNEP/IOC/IAEA. (1995). Determination of petroleum hydrocarbons in selected marine organisms. References methods for marine poll stud. $\mathrm{N}^{\circ} 72 \mathrm{UNEP}$.

[31]. Martens H, Næs T. (1989). Multivariate calibration. Chichester, UK: WILEY.

[32]. J. A. Daramola, F. O., Alao, S. A Osofero, and O. O. Wemimo, Assessment of the Microbial and Sensory Qualities of Smoked African Catfish (Clarias gariepinus), Journal of Agriculture and Environmental Sciences, (3), 2014, 11-22.

[33]. M. Cardinal, C. Knockaert, O. Torrissen, S. Sigurgisladottir, T. Morkore, M. Thomassen, and J.L. Vallet, Relation of smoking parameters to the yield colour and sensory quality of smoked Atlantic salmon (Salmo salar). Food Research International, 34 (6), 2001, 537-550.

[34]. M., Kalay, M.K., Sangün, D, Ayas and M. Göçer, Chemical composition and some trace element levels of thin lipped mullet, Liza ramada caught from Mersin Gulf, Journal of Ekoloji, 17, 68, 2008, 11-16. 
Determination of potential health hazards and nutritional attributes of the fresh and smoked ..

[35]. S. Belgin, M. Ünlüsayın, L. Izici, and A. Günlü, The determination of the shelf life and some nutritional components of gilhead seabream (Sparus aurata L., 1758) after cold and hot smoking, Turkish Journal of Veterinary and Animal Sciences, 32(1), 2008, 4956.

[36]. S.P. Aubourg, and M. Ugliano, Effect of brine pre-treatment on lipid stability of frozen horse mackerel (Trachurus trachurus), European Food Research Technology, 215, 2002, 91-95.

[37]. M., Espe, R., Nortvedt, O., Lie, and H. Hafsteinsson, Atlantic salmon (Salmo salar, L) as raw material for the smoking industry: Effect of different smoking methods on losses of nutrients and on the oxidation of lipids. Food Chemistry, 77, 2002, 41-46.

[38]. ICMSF: International Commission on Microbiological Specifications for Foods. (1998). Microorganisms in foods, 6: Microbial ecology of food commodities (p. 174-249). Baltimore, MD: Blackie Academic and Professional.

[39]. F.A. Çolakolu, The effects of processing techniques on microflora of roach (Rutilus rutilus) and whitefish (Coregonus sp.). Turkish Journal of Veterinary and Animal Sciences, 28(1), 2004, 239-247 .

[40]. S., Vasiliadou, I., Ambrosiadis, K., Vareltzis, D. Fletouris, and I. Gavriilidou, Effect of smoking on quality parameters of farmed gilthead sea bream (Sparus aurata L.) and sensory attributes of the smoked product. European Food Research Technology, 221, $2005,232-236$.

[41]. O.E. Salán, A.G. Juliana, O. Marilia, Use of smoking to add value to salmoned trout. Brazilian Archives of Biology and Technology, 49(1), 2006, 57-62.

[42]. A. Van Waarde, Biochemistry of non-protein nitrogenous compounds in fish including the use of amino acids for anaerobic energy production. Comparative biochemistry and physiology b-Biochemistry \& molecular biology, 91(2), 1988, 207-228.

[43]. C.A. Kumolu-Johnson, N.F. Aladetohun, and P.E. Ndimele, The effects of smoking on the nutritional qualities and shelf-life of Clarias gariepinus (BURCHELL 1822), African Journal of Biotechnology, 9(1), 2010, 073-076.

[44]. A.A. Mostafa, R.H. Salem, Characterization of Microbiological and Nutritional Variations in Processed Thin-lipped grey mullet (Liza ramada) Fish. Indian Journal of Medical Research, 6 (2), 2015, 108-122.

[45]. F., Leroi, and J.J. Joffraud, Salt and smoke simultaneously affect chemical and sensory quality of cold-smoked salmon during $5^{\circ} \mathrm{C}$ storage predicted using factorial design, Journal of Food Protection, 63(9), 2000, 1222-1227.

[46]. L.T., Hansen, T., Gill, and H.H. Huss, Effects of salt and storage temperature on chemical, microbiological and sensory changes in cold-smoked salmon, Journal of Food Research International, 28(2), 1995, 123-130.

[47]. J. Fernandez, J. A. Perez-Alvarez, and J. A. Fernandez-Lopez, Thiobarbituric acid test for monitoring lipid oxidation in meat, Food Chemistry, 59(3), 1997, 345-353.

[48]. J., Kanner, S., Harel and R. Jaffe, lipid-peroxidation of muscle food as affected by $\mathrm{NaCl}$. Journal of Agricultural and Food Chemistry. 39(6), 1991, 1017-1021.

[49]. P.E. Doe, (1998). Fish drying and smoking production and quality. (ed.). Lancaster: Technomic Publishing Co Inc. P: 89-115.

[50]. I.K. Khitouni, N.B. Mihoubi, A. Bouain, Ben, and F. Rebah, Seasonal variations in proximate and fatty acid composition of golden grey mullet Liza aurata $(\mathrm{R}, 1810)$ from the Tunisian coast. International Journal of Agricultural Policy and Research, 2 (7), 2014, 273-280.

[51]. S. Kheriji, M. El Cafsi, W. Masmoudi, J.D. Castell, and M.S. Romdhane, Salinity and temperature effects on the lipid composition of thin-lipped grey mullet sea fry (Liza ramada, Linne, 1758).,Aquaculture International, 11, 2003, 571-582.

[52]. N., Kalogeropoulos, T., Nomikos, A., Chiou, E. Fragopoulou, and Antonopoulou, S. Chemical composition of greek avgotaracho prepared from mullet (Mugil cephalus) : nutritional and health benefits. Journal of Agriculture and Food Chemistry. 56, 2008, $5916-5925$.

[53]. G.M., Lira, K.W., Barros Silva, B.C. Figueiredo, and N. Bragagnolo, Impact of smoking on the lipid fraction and nutritional value of seabob shrimp (Xiphopenaeus kroyeri, Heller, 1862), Journal of Food Science and Technology, 58, 2014, $183-187$.

[54]. G. Ozyurt, E. Kuley, S. Ozkutuk, F. Ozogul, Sensory, microbiological and chemical assessment of the freshness of red mullet (Mullus barbatus) and goldband goatfish (Upeneus moluccensis) during storage in ice, Food chemistry, 114, 2009, 505-510.

[55]. B. Ten Brink, C. Damink, H.M.J. Joosten, J.H.J. Huis In't Veld, Occurrence and formation of biologically active amines in foods. International Journal of Food Microbiology, 11, 1990, 73-84.

[56]. C. Ruiz-Capillas, A. Moral, Production of Biogenic amines and their potential use as quality control indices for hake (Merluccius merluccius) stored in ice, Journal of Food Science, 66, 2001, 1030-1032.

[57]. C. Ruiz-Capillas, A. Moral, Sensory and biochemical aspects of quality of whole bigeye tuna (Thunnus obesus) during bulk storage in controlled atmospheres. Food Chemistry, 89, 2005, 347-354.

[58]. H. Yamanaka, K. Shiomi, and T. Kikuchi, Cadaverine as a potential index for decomposition of salmonoid fishes, Journal of the Food Hygienic Society of Japan, 30, 1989, 170-174.

[59]. Church, N. MAP fish and crustaceans- sensory enhancement. Journal of Food Science and Technology, 12 (2), 1998, 73-83.

[60]. M.A. Mazorra-Manzano, R. Pacheco-Aguilar, E.I. Diaz-Rojas and M.E. Lugo-Sanchez, Postmortem changes in black skipjack muscle during storage in ice. Journal of Food Sciences, 65, 2000, 774-779.

[61]. Y. Özoğul, E.K. Boğa, B. Tokurl, F. Özoğul, Changes in biochemical, sensory and microbiological quality indices of common sole (Solea solea) from the Mediterranean sea, during ice storage. Turkish Journal of Fisheries and Aquatic Sciences, 11, 2011, $243-251$.

[62]. S.P. Aubourg, V. Quitral, M.A. Larrain, A. Rodriguez, J. Gomez, L. Maier, and J. Vinagre, Autolytic degradation and microbiological activity in farmed Coho salmon (Oncorhynchus kisutch) during chilled storage, Food Chemistry, 104, 2007, 369375.

[63]. T. Saito, K. Arai and M. Matsuyoshi, A new method for estimating the freshness of fis, Bulletin of the Japanese Society for the Science of Fish, 24, 1959, 749-750.

[64]. S. Da Costa Silva Andrade, E. Teixeira Mársico, R. Luiz de Oliveira Godoy, S. Pacheco, R Maia Franco, S. Borges Mano, and C. Adam Conte- Junior, Chemical Quality Indexes of Mullet (Mugil platanus) Stored on Ice. Journal of Food and Nutrition Sciences, 5, 2014, 1030-1039.

[65]. H.H. Huss, Postmortem changes in fish. In: Quality and quality changes in fresh fish". FAO Fisheries. Technical Paper No. 348, Rome, pp. 169. (1995).

[66]. P.K. Reddi, S.M. Constantinides, H.A. Dymsza, Catheptic activity of fish muscle, Journal of Food Science, 37, 1972, 643-648.

[67]. C. Delbarre-Ladrat, R. Chéret, R. Taylor, V. Verrez-Bagnis, Trends in postmortem aging in fish: understanding of proteolysis and disorganization of the myofibrillar structure. Critical reviews in food science and nutrition, 46, 2006, 409-421.

[68]. K.E. Lund and H.H. Nielsen, Proteolysis in salmon (Salmo salar) during cold storage; Effects of storage time and smoking process, Journal of Food Biochemistry, 25(5), 2001. 379-395.

[69]. E., Huff-Lonergan, and S.M. Lonergan, Mechanisms of water-holding capacity of meat: the role of postmortem biochemical and structural changes, Meat Science, 71, 2005, 194-204. 
[70]. Hultmann, L., Røra, A.M.B., Steinsland, I., Skara, T., \& Rustad, T. (2003). Proteolytic activity and properties of proteins in smoked salmon (Salmo salar). Effects of smoking temperature. Food Chemistry, 85(3), 377-387.-

[71]. S.K. Jasra, P.K. Jasra, and C.L. Talesara, Myofibrillar protein degradation of carp (Labeo rohita (Hamilton)) muscle after postmortem unfrozen and frozen storage, Journal of Science Food Agriculture, 81(5), 2001, 519-524.

[72]. S. Moret, LS. Conte, Polycyclic aromatic hydrocarbon in edible fats and oils: Occurence and analytical methods, Journal of Chromatography A, 882, 2000, 245-253.3

[73]. F., Swastawati, T., Surti, D. Apriliani, Analysis of thiobarbutric acid and benzo( $\alpha$ )pyrène value of smoked nile tilapia (Oreochromis niloticus) using different liquid smokes, Journal of Coastal Development, 13(3), 2010, 160-165.

[74]. Europeen Comission (EC). Commission Regulation No 835/2011 of 19 August 2011. L 215. P4.

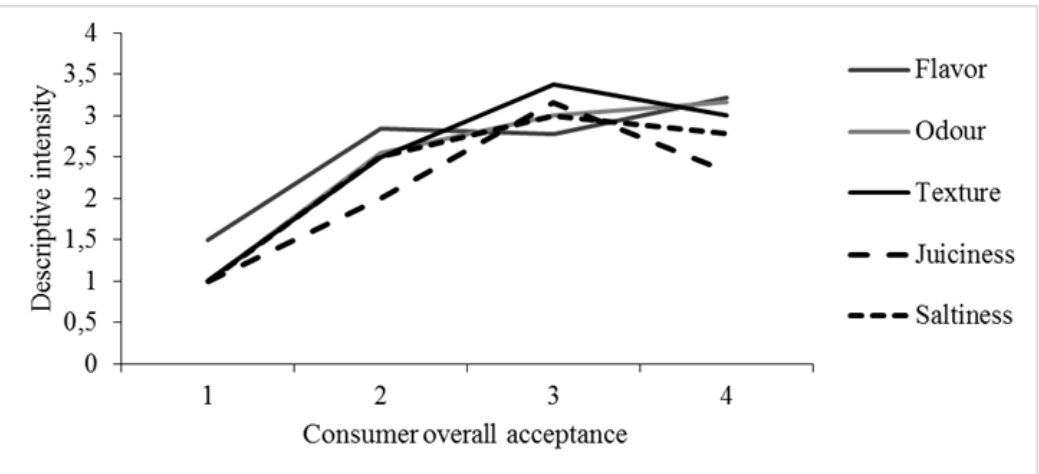

Fig. 1. Sensory evaluation of cold smoked fillets of freshwater mullet (Liza ramada)
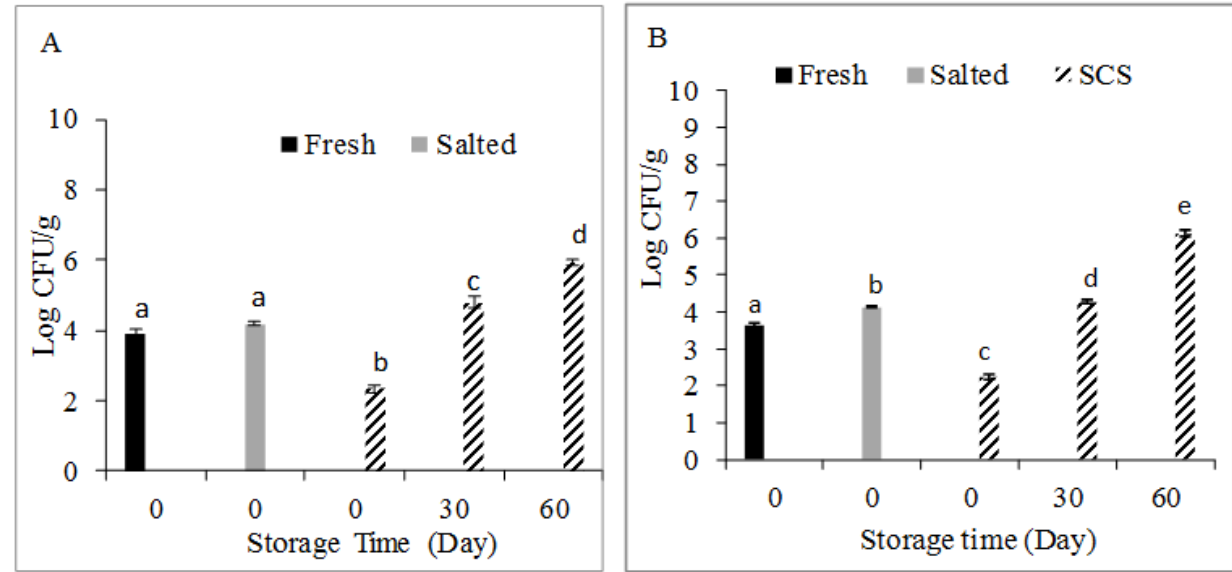

Fig. 2: Freshwater mullet (Liza ramada): (A) Changes in mesophilic and (B) psychrophilic counts of fresh, salted and salted cold smoked fillets (SCS) following various periods of refrigerated storage (day). Data are mean \pm standard deviation $(n=6$ in each case). Means within the same row with different superscript are significantly different $(\mathrm{p}<0.05)$.

A

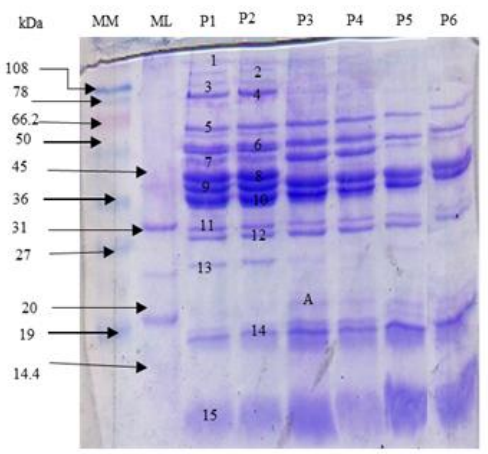

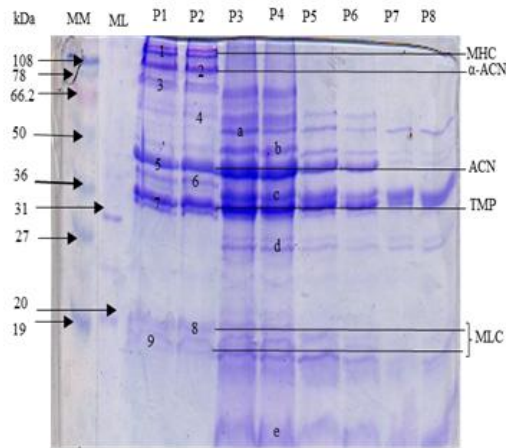

Fig. 3: Freshwater mullet (Liza ramada): Electrophoretic profile of (A) Sarcoplasmic proteins of fresh (P1, P2), salted and smoked fillets after 1 day (P3, P4), 30 days (P5), and 60 days (P6) of refrigerated storage, and (B) Myofibrillar proteins of fresh fillets (P1, P2), salted and smoked fillets after 1 day (P3, P4), 30 days (P5, P6), and 60 days of refrigerated storage (P7, P8). MM: Medium protein molecular weight markers, ML: Low protein molecular weight markers. 


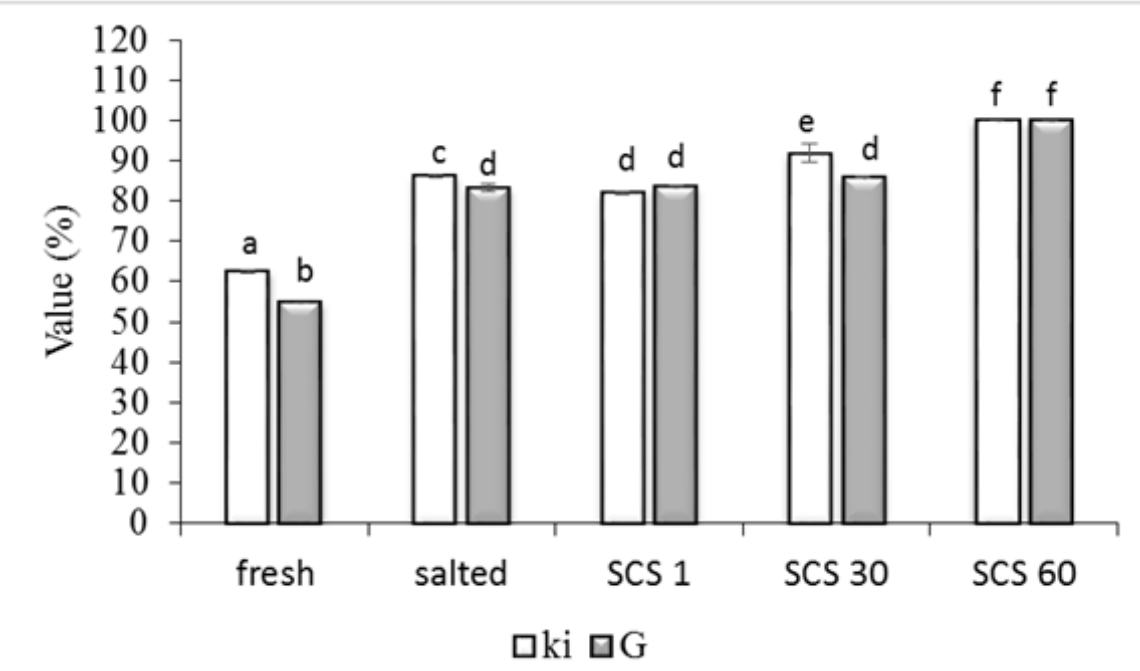

Fig. 4: Freshwater mullet (Liza ramada): Ki, and G values in fresh, salted and salted cold smoked fillets (SCS) following various periods of refrigerated storage (day).

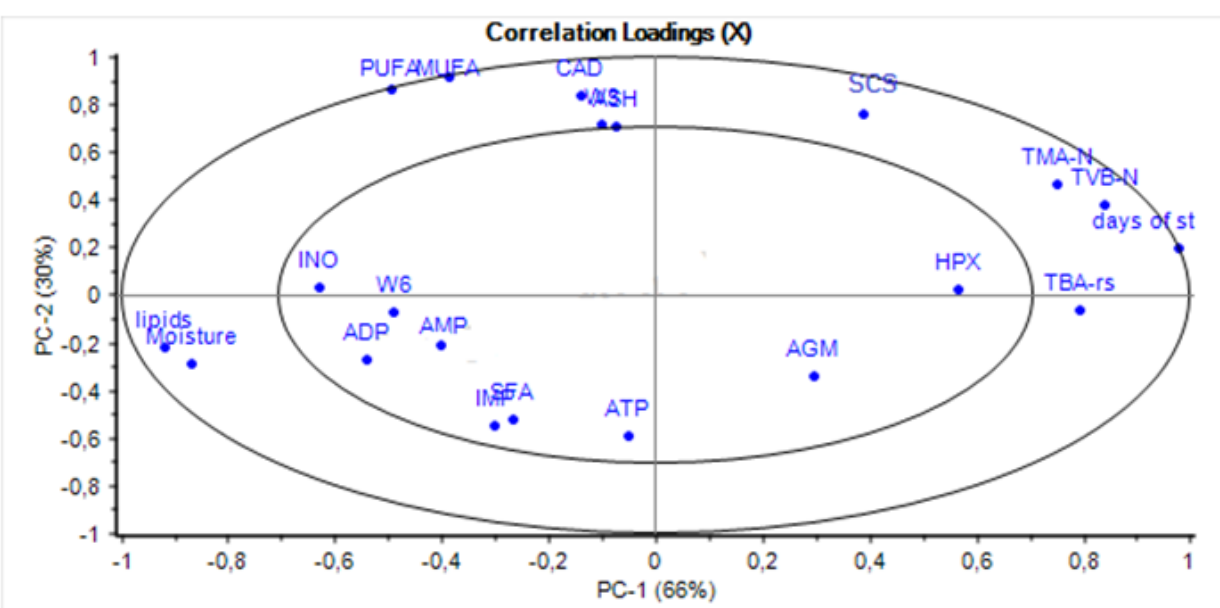

Fig. 5. Freshwater mullet (Liza ramada): Loading plot from principal component analysis (PCA) of cold smoked (SCS) fillets with their chemical values [Moisture, ash (ASH), Lipids, TMA-N, TVB-N, TBArs, SFA, MUFA, PUFA, w3, w6, cadaverine (CAD), agmatine (AGM), hypoxanthine (HYP), adenosine 5'-diphosphate (ADP), adenosine 5'-monophosphate (AMP), inosine 5' monophosphate (IMP), inosine (INS) and hypoxanthine (HPX) and relative changes during storage (days of st).

Table 1: Freshwater mullet (Liza ramada): Proximate composition of fresh, salted and salted/cold smoked fillets following different period of refrigerated storage at $2^{\circ} \mathrm{C}$. Data are mean \pm standard deviation $(n=6$ in each case). Means within the same row with different superscript are significantly different $(p<0.05)$.

\begin{tabular}{|c|c|c|c|c|c|c|c|}
\hline Fillet treatment & Fresh & Salted & & & ed cold smoked & & \\
\hline Day of storage & 0 & 0 & 0 & 15 & 30 & 45 & 60 \\
\hline $\begin{array}{l}\text { Moisture } \\
\text { (\%) }\end{array}$ & $78.31 \pm 0.53 a$ & $72.482 \pm 0.36 \mathrm{~b}$ & $66.71 \pm 1.23 \mathrm{c}$ & $68.67 \pm 2.14 \mathrm{c}$ & $66.19 \pm 0.23 \mathrm{c}$ & $66.33 \pm 2.4 \mathrm{c}$ & $56.6 \pm 2.26 \mathrm{~d}$ \\
\hline $\operatorname{Ash}(\mathrm{mg} / 100 \mathrm{~g})$ & $0.76 \pm 0.15 \mathrm{a}$ & $3.3 \pm 0.49 \mathrm{~b}$ & $5.43 \pm 0.83 \mathrm{c}$ & $4.55 \pm 0.76 \mathrm{c}$ & $4.34 \pm 0.37 \mathrm{c}$ & $3.76 \pm 0.14 \mathrm{~d}$ & $3.14 \pm 0.14 \mathrm{~d}$ \\
\hline $\begin{array}{l}\text { Total lipid } \\
(\mathrm{g} / 100 \mathrm{~g})\end{array}$ & $4.55 \pm 0.35 \mathrm{a}$ & $4.06 \pm 0.47 \mathrm{~b}$ & $4.15 \pm 0.15 b$ & $3.69 \pm 0.33 c$ & $2.4 \pm 0.34 \mathrm{~d}$ & $2 \pm 0.14 \mathrm{e}$ & $1.51 \pm 0.13 \mathrm{f}$ \\
\hline Protein $(\mathrm{g} / 100 \mathrm{~g})$ & $17.9 \pm 0.4 a$ & - & $18.84 \pm 1.06 \mathrm{a}$ & - & $16.9 \pm 1.1 \mathrm{~b}$ & - & $9.73 \pm 0.15 \mathrm{c}$ \\
\hline
\end{tabular}

(-): analysis not performed 
Determination of potential health hazards and nutritional attributes of the fresh and smoked ..

Table 2: Freshwater mullet (Liza ramada): Changes in total volatile bases (TVB-N), Trimethylamine (TMA-N), Thiobarbutric acid (TBA) of fresh, salted and salted/cold smoked fillets at different periods of refrigerated storage. Data are mean \pm standard deviation $(n=6$ in each case). Means within the same row with different superscript are significantly different $(\mathrm{p}<0.05)$.

\begin{tabular}{|c|c|c|c|c|c|c|c|}
\hline & Fresh & Salted & & & Salted cold sn & & \\
\hline $\begin{array}{l}\text { Day of } \\
\text { storage }\end{array}$ & 0 & 0 & 1 & 15 & 30 & 45 & 60 \\
\hline TVB-N & $9.96 \pm 0.74 a$ & $7.17 \pm 0.27 b$ & $11.95 \pm 0.82 \mathrm{c}$ & $13.14 \pm 1.8 \mathrm{c}$ & $14.2 \pm 0.8 c$ & $15.4 \pm 0.55 \mathrm{c}$ & $23.95 \pm 0.71 \mathrm{~d}$ \\
\hline TMA-N & $1.27 \pm 0.36 \mathrm{a}$ & $1.61 \pm 0.21 \mathrm{a}$ & $4.1 \pm 0.41 \mathrm{~b}$ & $7.48 \pm 0.35 c$ & $8.83 \pm 0.74 d$ & $11.02 \pm 1.17 \mathrm{e}$ & $15.05 \pm 0.62 \mathrm{f}$ \\
\hline TBA-rs & $0.18 \pm 0.04 a$ & $0.82 \pm 0.07 \mathrm{~b}$ & $0.27 \pm 0.04 c$ & $0.3 \pm 0.04 c$ & $0.37 \pm 0.03 d$ & $0.73 \pm 0.12 \mathrm{e}$ & $1.68 \pm 0.2 f$ \\
\hline
\end{tabular}

Table 3: Freshwater mullet (Liza ramada): Changes in biogenic amines in fresh and salted/cold smoked fillets during refrigerated storage. Data are mean \pm standard deviation $(n=3$ in each case). Means within the same row with different superscript are significantly different $(\mathrm{p}<0.05)$.

\begin{tabular}{|c|c|c|c|c|c|}
\hline & & $\begin{array}{c}\text { Agmatine } \\
(\mathrm{mg} / \mathrm{kg})\end{array}$ & $\begin{array}{c}\text { Cadaverine } \\
(\mathrm{mg} / \mathrm{kg})\end{array}$ & $\begin{array}{l}\text { Histamine } \\
(\mathrm{mg} / \mathrm{kg})\end{array}$ & $\begin{array}{l}\text { Spermine } \\
(\mathrm{mg} / \mathrm{kg})\end{array}$ \\
\hline & Fresh fillets & $27.35 \pm 3.75 \mathrm{a}$ & - & $1.425 \pm 0.44 \mathrm{a}$ & $2.128 \pm 0.17 \mathrm{a}$ \\
\hline \multirow{4}{*}{ 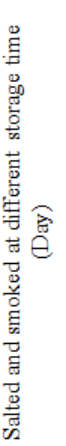 } & (1) & $13 \pm 1.61 \mathrm{~b}$ & $3.22 \pm 0.29 \mathrm{~b}$ & - & - \\
\hline & (30) & $14.19 \pm 2.39 \mathrm{~b}$ & $6.71 \pm 0.69 \mathrm{~b}$ & - & - \\
\hline & (45) & $18.83 \pm 7.31 \mathrm{~b}$ & $5.44 \pm 0.70 \mathrm{~b}$ & - & - \\
\hline & $(60)$ & $33.72 \pm 2.34 \mathrm{c}$ & $9.21 \pm 2.88 \mathrm{c}$ & - & - \\
\hline
\end{tabular}

Table 4: Freshwater mullet (Liza ramada): Changes in fatty acids composition (\%) of fresh, salted and salted/cold smoked fillets. Data are mean \pm standard deviation $(n=3$ in each case). Means within the same row with different superscript are significantly different $(\mathrm{p}<0.05)$.

\begin{tabular}{|c|c|c|c|c|c|c|}
\hline & \multicolumn{6}{|c|}{ Salted and smoked at different storage time (day) } \\
\hline & Fresh & Salted & $(0)$ & $(30)$ & $(45)$ & $(60)$ \\
\hline (C14:0) & $6.56 \pm 0.28 \mathrm{a}$ & $7.95 \pm 0.86 \mathrm{a}$ & $6.54 \pm 0.22 \mathrm{a}$ & $7.97 \pm 0.66 \mathrm{a}$ & $7.12 \pm 0.06 \mathrm{a}$ & $7.52 \pm 0.53 \mathrm{a}$ \\
\hline (C15:0) & $1.87 \pm 0.15 \mathrm{a}$ & $1.68 \pm 0.17 \mathrm{a}$ & $1.68 \pm 0.07 \mathrm{a}$ & $1.94 \pm 0.13 \mathrm{~b}$ & $1.56 \pm 0.18 \mathrm{a}$ & $1.78 \pm 0.16 \mathrm{a}$ \\
\hline$(\mathrm{C} 16: 0)$ & $34.32 \pm 0.77 \mathrm{a}$ & $40.34 \pm 3.06 \mathrm{~b}$ & $33.15 \pm 0.93 \mathrm{c}$ & $34.95 \pm 1.33 \mathrm{c}$ & $35.48 \pm 0.69 \mathrm{c}$ & $35.16 \pm 1.04 \mathrm{c}$ \\
\hline (C16:1 w7) & $12.70 \pm 0.86 \mathrm{a}$ & $10.24 \pm 0.77 \mathbf{a}$ & $11.36 \pm 1.19 \mathrm{a}$ & $14.58 \pm 0.38 \mathrm{~b}$ & $13.25 \pm 0.39 \mathrm{~b}$ & $15.18 \pm 1.47 \mathrm{~b}$ \\
\hline$(\mathrm{C} 16: 2 \mathrm{w} 4)$ & $0.76 \pm 0.2 \mathrm{a}$ & $0.97 \pm 0.08 a$ & $1.45 \pm 0.11 \mathrm{~b}$ & $1.62 \pm 0.01 \mathrm{~b}$ & $1.41 \pm 0.1 \mathrm{~b}$ & $1.60 \pm 0.18 \mathrm{~b}$ \\
\hline (C16:3w4) & $1.32 \pm 0.05 \mathrm{a}$ & $1.64 \pm 0.33 \mathrm{a}$ & $1.68 \pm 0.11 \mathrm{a}$ & $1.98 \pm 0.05 \mathrm{~b}$ & $1.84 \pm 0.07 \mathrm{~b}$ & $2.31 \pm 0.03 c$ \\
\hline (C18:0) & $7.71 \pm 0.53 \mathrm{a}$ & $6.59 \pm 0.55 \mathrm{~b}$ & $7.04 \pm 1.41 \mathrm{c}$ & $4.28 \pm 0.13 \mathrm{c}$ & $4.80 \pm 0.29 \mathrm{~d}$ & $4.22 \pm 0.09 \mathrm{~d}$ \\
\hline (C18:1 w9) & $9.52 \pm 0.6 \mathrm{a}$ & $7.98 \pm 0.06 \mathrm{~b}$ & $10.12 \pm 0.88 \mathrm{a}$ & $9.14 \pm 0.92 \mathrm{a}$ & $10.51 \pm 0.18 \mathrm{a}$ & $10.39 \pm 0.64 \mathrm{a}$ \\
\hline (C18:1 w7) & $1.86 \pm 0.09 \mathrm{a}$ & $1.17 \pm 0 \mathrm{~b}$ & $1.34 \pm 0.07 \mathrm{~b}$ & $1.47 \pm 0.2 \mathrm{c}$ & $1.67 \pm 0.09 \mathrm{c}$ & $1.75 \pm 0.02 c$ \\
\hline (C18:2w6) & $6.20 \pm 0.27 \mathrm{a}$ & $4.01 \pm 0.53 \mathrm{~b}$ & $4.71 \pm 0.36 \mathrm{~b}$ & $3.82 \pm 0.04 \mathrm{c}$ & $3.84 \pm 0.15 \mathrm{c}$ & $3.73 \pm 0.12 \mathrm{c}$ \\
\hline (C18:3 w4) & $0.22 \pm 0.01 \mathrm{a}$ & $0.00 \pm 0 \mathrm{~b}$ & $0.00 \pm 0 \mathrm{~b}$ & $0.19 \pm 0 \mathrm{c}$ & $0.17 \pm 0 \mathrm{c}$ & $0.17 \pm 0.01 \mathrm{c}$ \\
\hline (C18:3 w3) & $3.93 \pm 0.17 \mathrm{a}$ & $4.68 \pm 0.73 \mathrm{~b}$ & $5.06 \pm 0.47 \mathrm{~b}$ & $4.10 \pm 0.34 \mathrm{a}$ & $4.30 \pm 0.21 \mathrm{a}$ & $4.51 \pm 0.12 \mathrm{~b}$ \\
\hline (C18:4w3) & $1.11 \pm 0.15 \mathrm{a}$ & $1.28 \pm 0.12 \mathrm{a}$ & $1.41 \pm 0.04 \mathrm{~b}$ & $1.11 \pm 0.19 \mathrm{a}$ & $1.30 \pm 0.09 \mathrm{a}$ & $1.43 \pm 0.02 \mathrm{~b}$ \\
\hline (C20:1 w9) & $0.00 \pm 0.00 \mathrm{a}$ & $0.21 \pm 0 \mathrm{~b}$ & $0.54 \pm 0.03 c$ & $0.00 \pm 0 \mathrm{a}$ & $0.00 \pm 0 \mathrm{a}$ & $0.00 \pm 0 \mathrm{a}$ \\
\hline (C20:4 w6) & $1.49 \pm 0.12 \mathrm{a}$ & $1.07 \pm 0.26 \mathrm{~b}$ & $1.37 \pm 0.14 \mathrm{~b}$ & $1.12 \pm 0.17 \mathrm{~b}$ & $1.46 \pm 0.03 \mathrm{a}$ & $1.30 \pm 0.07 \mathrm{a}$ \\
\hline (C20:4w3) & $0.14 \pm 0.01 \mathrm{a}$ & $0.16 \pm 0.04 \mathrm{~b}$ & $0.22 \pm 0.03 c$ & $0.19 \pm 0.02 c$ & $0.19 \pm 0.02 \mathrm{c}$ & $0.16 \pm 0.03 \mathrm{~b}$ \\
\hline (C20:5 w3) & $1.80 \pm 0.01 \mathrm{a}$ & $2.44 \pm 0.67 \mathrm{a}$ & $3.30 \pm 0.46 \mathrm{~b}$ & $2.74 \pm 0.34 \mathrm{~b}$ & $2.98 \pm 0.11 \mathrm{~b}$ & $3.14 \pm 0.11 \mathrm{~b}$ \\
\hline (C22:5 w3) & $0.33 \pm 0.03 \mathrm{a}$ & $0.26 \pm 0.06 \mathrm{a}$ & $0.41 \pm 0.05 \mathrm{a}$ & $0.36 \pm 0.01 \mathrm{a}$ & $0.33 \pm 0.03 a$ & $0.30 \pm 0.01 \mathrm{a}$ \\
\hline$(\mathrm{C} 22: 6 \mathrm{w} 3)$ & $0.70 \pm 0.07 a$ & $0.54 \pm 0.17 \mathrm{~b}$ & $0.94 \pm 0.23 c$ & $0.69 \pm 0.1 \mathrm{~d}$ & $0.98 \pm 0.11 \mathrm{~d}$ & $0.70 \pm 0.05 \mathrm{~d}$ \\
\hline TOTAL & $92.32 \pm 0.6 \mathrm{a}$ & $91.74 \pm 3.01 \mathrm{a}$ & $92.13 \pm 0.61 \mathrm{a}$ & $92.13 \pm 1.05 \mathrm{a}$ & $93.08 \pm 0.34 \mathrm{a}$ & $92.48 \pm 0.53 \mathrm{a}$ \\
\hline$\sum$ PUFA & $17.78 \pm 0.11 \mathrm{a}$ & $19.57 \pm 1.31 \mathrm{~b}$ & $20.54 \pm 0.42 \mathrm{~b}$ & $17.91 \pm 1.24 \mathrm{~b}$ & $18.70 \pm 0.73 \mathrm{~b}$ & $18.90 \pm 0.93 \mathrm{~b}$ \\
\hline ¿MUFA & $24.08 \pm 1.5 \mathrm{a}$ & $19.46 \pm 0.93 \mathrm{~b}$ & $23.18 \pm 1.44 \mathrm{a}$ & $24.47 \pm 0.22 \mathrm{a}$ & $25.03 \pm 0.86 \mathrm{a}$ & $25.25 \pm 0.78 \mathrm{a}$ \\
\hline$\sum$ SFA & $48.59 \pm 0.92 \mathrm{a}$ & $54.8 \pm 3.9 \mathrm{~b}$ & $47.95 \pm 1.7 \mathrm{a}$ & $47.20 \pm 2.09 \mathrm{a}$ & $47.39 \pm 0.99 \mathrm{a}$ & $46.90 \pm 1.49 \mathrm{a}$ \\
\hline$\sum \mathrm{n}-3$ & $7.86 \pm 0.11 \mathrm{a}$ & $10.67 \pm 0.81 \mathrm{~b}$ & $11.33 \pm 0.39 \mathrm{~b}$ & $9.19 \pm 0.99 \mathrm{~b}$ & $10.07 \pm 0.49 \mathrm{~b}$ & $10.36 \pm 0.46 \mathrm{~b}$ \\
\hline$\sum \mathrm{n}-6$ & $7.69 \pm 0.28 \mathrm{a}$ & $5.07 \pm 0.6 \mathrm{~b}$ & $6.08 \pm 0.3 b$ & $4.93 \pm 0.2 c$ & $5.30 \pm 0.16 \mathrm{c}$ & $5.03 \pm 0.18 \mathrm{c}$ \\
\hline IA & $1.68 \pm 0.08 \mathrm{a}$ & $1.68 \pm 0.36 \mathrm{a}$ & $1.56 \pm 0.01 \mathrm{a}$ & $1.72 \pm 0.26 \mathrm{a}$ & $1.69 \pm 0.05 \mathrm{a}$ & $1.67 \pm 0.08 \mathrm{a}$ \\
\hline IT & $1.67 \pm 0.04 a$ & $1.2 \pm 0.3 \mathrm{~b}$ & $1.2 \pm 0.01 \mathrm{~b}$ & $1.41 \pm 0.28 \mathrm{~b}$ & $1.37 \pm 0.08 \mathrm{~b}$ & $1.39 \pm 0.12 \mathrm{~b}$ \\
\hline
\end{tabular}


Determination of potential health hazards and nutritional attributes of the fresh and smoked ..

Table 5: Freshwater mullet (Liza ramada): Comparison of PAHs concentrations $\left(\mathrm{ng}^{-1}\right)$ in fresh and salted/cold smoked fillets

\begin{tabular}{lcc}
\hline Compounds & Fresh & Salted and smoked \\
\hline Naphthalene & 0.03 & 0.08 \\
\hline Acenaphthylene & 0.25 & 0.38 \\
\hline Acenaphthene & 0.10 & 0.21 \\
\hline Fluorene & 0.09 & 0.19 \\
\hline Phenanthrene & - & 0.86 \\
\hline Anthracene & 0.12 & 0.06 \\
\hline Fluranthene & 0.01 & 0.20 \\
\hline Pyrene & 0.11 & 0.25 \\
\hline Benzo(a)anthracene & 0.07 & - \\
\hline Chrysene & - & 0.22 \\
\hline Benzo(b)fluoranthene & - & - \\
\hline Benzo(k)fluoranthene & - & - \\
\hline Benzo(a)pyrene & - & - \\
\hline indeno(123c)pyrene & - & - \\
\hline Dibenz(ah)anthracene & - & - \\
\hline benzo(ghi)perylene & - & 2.45 \\
\hline Naphthalene & 0.78 & \\
\hline$\sum$ (chrysene. benzo(b)fluoranthene. & & \\
\hline benz(a)anthracene. Benzo(a)pyrene) & & - \\
\hline$\sum$ PAHs & - & \\
\hline
\end{tabular}

(-): Not Detected 